\title{
Diseminasi Pengelolaan Keuangan Rumah Tangga: Perencanaan Pensiun
}

\author{
Farida Komalasari $^{1}$, Eko Ganiarto ${ }^{2)}$ \\ ${ }^{1)}$ Fakultas Bisnis, Universitas Presiden, farida_k@president.ac.id \\ ${ }^{2)}$ Fakultas Bisnis, Universitas Presiden, eganiarto@president.ac.id
}

\begin{abstract}
ABSTRAK
Kegiatan ini ditujukan untuk meningkatkan kesadaran masyarakat dalam menata keuangan rumah tangga, khususnya dalam melakukan perencanaan pensiun. Diharapkan dengan melakukan perencanaan pensiun yang tepat, seseorang tidak mengalami penurunan kesejahteraan dalam menjalani usia pensiunnya. Kegiatan ini juga dimaksudkan untuk meningkatkan literasi keuangan keluarga. Kegiatan ini dilaksanakan pada Minggu, 3 November 2019 jam 16.00-18.00 di kelompok sasaran Komunitas Ibu RT 09 RW 03 Kelurahan Dukuh Kecamatan Kramat Jati Jakarta Timur. Sejumlah 18 anggota komunitas hadir dalam kegiatan ini. Diseminasi dilaksanakan dengan metode ceramah, benar atau salah, guided teaching, tanya jawab, simulasi, dan diskusi. Sejak awal hingga akhir acara, peserta sangat aktif. Pertanyaan dan tanggapan dari peserta menunjukkan kesadaran mereka tentang pentingnya melakukan perencanaan pensiun. Setelah mengikuti kegiatan, peserta menilai bahwa memiliki perencanaan pensiun adalah penting sebelum memasuki usia pensiun. Perencanaan pensiun diperlukan untuk meraih kondisi pensiunan yang sejahtera. Masalahnya adalah mereka belum memiliki pengetahuan yang cukup untuk melakukan perencanaan pensiun dengan baik. Oleh karena itu diperlukan bimbingan dan pendampingan secara berkelanjutan untuk meningkatkan literasi keuangan mereka, terutama dalam melakukan perencanaan pensiun. Di masa yang akan datang diperlukan kegiatan bimbingan dan pendampingan dalam menyusun rencana pensiun, sesuai kemampuan dan kebutuhan masing-masing. Beberapa topik yang perlu diberikan adalah pengenalan terhadap instrumen-instrumen investasi dan kiat memilih Dana Pensiun Lembaga Keuangan (DPLK).
\end{abstract}

Kata-kata Kunci: Pengelolaan Keuangan Rumah Tangga, Pensiun, Perencanaan Pensiun, Investasi, DPLK

\section{ABSTRACT}

This community empowerment activity is intended to improve people awareness in financial household management, especially in retirement planning. By doing a good retirement planning, it is expected that people will have a good quality of life during their retirement. This activity is also intended to increase households' financial literacy. This activity was done at Sunday, 3 November 2019 at 4-6pm, participated by 18 members of Komunitas Ibu RT 09 RW 03 Kelurahan Dukuh Kecamatan Kramat Jati Jakarta Timur. Lecturing, true or fals, guided teaching, question \& answer, simulation and discusion were used along this activity. All participants were actively following the all program, from the beginning to the end of session. Questions and opinions from participants show their awareness on the importance of retirement planning. At the end of session, the participants agreed that having a good retirement planning before entering the retirement period is important. Retirement planning is needed to reach a good wealth during the retirement. The problem is that they do not have an enough knowledge to make a good retirement planning. Therefore, a guidance and help are needed to increase their financial literacy, especially in composing a retirement plan. Some topics that could be delivered to them in the future are introducing investment instruments and selecting a Financial Institution Pension Fund.

Keywords: Household Financial Management, Retirement, Retirement Planning, Investment, Pension Plan Financial Institution

\section{PENDAHULUAN}

Angka lierasi keuangan di Indonesia pada tahun 2018 adalah 67,8\% (OJK, 2017). Angka ini lebih rendah dibandingkan dengan Malaysia (81\%), Thailand (78\%), dan 
Singapura (96\%) (OJK, 2016a). Sebagaimana disampaikan oleh Tirta Segara, anggota Dewan Komisioner Bidang Edukasi dan Perlindungan Konsumen OJK, literasi keuangan khususnya literasi keuangan keluarga merupakan salah satu pilar perekonomian karena kesehatan keuangan keluarga berpengaruh pada kesehatan keuangan negara (Kontan, 4 Oktober 2017).

Rendahnya literasi keuangan tersebuit mengakibatkan kurang baiknya pengelolaan keuangan rumah tangga, termasuk rendahnya perencanaan pensiun. Dikutip dari Komalasari \& Hani (2018), menurut penelitian yang dilakukan oleh Employee Benefit Research Institute (EBRI), dari 100\% pekerja yang menjalani pensiun dini, $75 \%$ diantaranya adalah pensiun dini karena "dipaksa" oleh perusahaan tempatnya bekerja meskipun mereka belum mempersiapkan diri dengan baik masa pensiunnya. Fakta lain menunjukkan bahwa melalui sebuah kegiatan diseminasi pola pengelolaan keuangan rumah tangga yang dilakukan oleh Komalasari dan Ganiarto (2018), dari 26 peserta yang hadir tidak satu pun yang telah memiliki perencanaan pensiun.

Sebagai sebuah perguruan tinggi yang menyelenggarakan Program Studi IImu Administrasi Bisnis dengan Konsentrasi Wealth Planning, selayaknya ikut berperanserta dalam upaya peningkatan literasi keuangan rumah tangga. Oleh karenanya proposal ini disusun dengan tujuan untuk melakukan diseminasi pola pengeloaan keuangan rumah tangga, khususnya dalam perencanaan pensiun untuk meningkatkan kesehatan keuangan rumah tangga sekaligus meningkatkan literasi keuangan keluarga.

Di tengah melemahnya pertumbuhan ekonomi, kasus pemutusan hubungan kerja dan tawaran pensiun dini meningkat. Sebagai contoh diantaranya adalah tawaran pensiun dini yang dilakukan oleh Kementerian Perikanan dan Kelautan. Kementerian ini menawarkan program pensiun dini dengan tujuan meningkatkan efsisensi dan kinerja lembaga dengan menyisakan pegawai yang berkualitas (Sukmana, 2017). Program ini tidak mendapatkan tanggapan yang memadai karena sebagian besar dari mereka belum melakukan perencanaan pensiun (Komalasari \& Hani, 2018).

Di beberapa perusahaan lain, program pensiun dini ditawarkan untuk mengurangi jumlah karyawan senior yang kurang mampu beradaptasi dengan kemajuan teknologi yang diperlukan untuk meningkatkan kinerja perusahaan. Hal ini dilakukan oleh perusahaanperusahaan yang operasinya mengandalkan teknologi (technological-based company). Diantaranya adalah usaha pertelevisian, peritel yang mengadopsi penerpana on-line business, dan lain-lain. Di tengah pesatnya perkembangan teknologi informasi dan digitaltechnology, maka kasus pensiun dini seperti ini akan meningkat di masa yang akan datang. Sementara itu, siapkah mereka menghadapi program pensiun dini dan sudahkan mereka melakukan perencanaan pensiun? 
Kegiatan yang dilakukan oleh Komalasari \& Ganiarto (2018) menunjukkan bahwa dari sejumlah 26 orang peserta diseminasi pola pengelolaan keuangan rumah tangga, tidak satu pun yang telah melakukan perencanaan pensiun.

Ketiga kasus di atas cukup untuk menyatakan bahwa kesadaran rumah tangga di Indonesia untuk melakukan perencanaan pensiun masih sangat kurang. Kurangnya kesadaran merupakan salah satu bukti rendahnya literasi keuangan rumah tangga. Dengan demikian diperlukan kegiatan diseminasi pengelolaan keuangan rumah tangga, khususnya dalam hal perencanaan pensiun.

Tujuan kegiatan pengabdian kepada masyarakat (PKM) ini adalah untuk meningkatkan kesadaran pentingnya membuat perencanaan pensiun dan cara melakukan perencanaan pensiun dengan baik. Sedangkan manfaat kegiatan ini adalah meningkatkan kesadaran atas pentingnya menyusun perencanaan pensiun, m meningkatkan kemampuan masyarakat dalam menyusun perencanaan pensiun, meningkatkan literasi keuangan para pengelola keuangan rumah tangga, dan meningkatkan kesiapan keuangan di masa pensiun.

Sasaran kegiatan ini adalah para pekerja aktif (usia produktif) di lingkungan RT 09 RW 03 Kelurahan Dukuh Kecamatan Kramat Jati Jakarta Timur.

\section{METODE PELAKSANAAN}

\subsection{Tahapan dan Jadwal Kegiatan}

Tahapan kegiatan beserta jadwal kegiatan disajikan pada Tabel 1.

Tabel 1.

Tahapan dan Jadwal Kegiatan

\begin{tabular}{|c|l|c|c|c|c|c|c|}
\hline \multirow{2}{*}{ No. Kegiatan } & \multicolumn{5}{c|}{ Bulan Ke- } \\
\cline { 5 - 7 } & & 1 & 2 & 3 & 4 & 5 & 6 \\
\hline 1 & Penyusunan Proposal & & & & & & \\
\hline 2 & $\begin{array}{l}\text { Persiapan Kerjasama } \\
\text { dengan Komunitas }\end{array}$ & & & & & \\
\hline 3 & Penyusunan Modul & & & & & & \\
\hline 4 & Persiapan \& Pelaksanaan & & & & & & \\
\hline 5 & $\begin{array}{l}\text { Penyusunan Laporan \& } \\
\text { Pelaporan }\end{array}$ & & & & & \\
\hline 6 & $\begin{array}{l}\text { Pengiriman Artikel ke } \\
\text { Jurnal PKM }\end{array}$ & & & & & \\
\hline
\end{tabular}

\subsection{Rincian Kegiatan}

Metode ceramah dan active learning digunakan dalam kegiayan yang berdurasi 2 jam ini. Teknik active-learning yang digunakan meliputi:

a. True or False: untuk menjajagi tingkat literasi keuangan peserta tentang perencanaan pensiun 
b. Giuded teaching: untuk memberikan pengetahuan tentang pensiun, usia pensiun, pensiunan yang sejahtera, prinsip-prinsip dalam melakukan perencanaan pensiun, dan lain-lain.

c. Simulation: untuk memberikan contoh perhitungan dalam melyusun rencana pensiun

d. Tanya jawab dan diskusi: untuk mendalami kasus dan merangkum materi diseminasi.

\subsection{Bahan/Peralatan}

Bahan dan peralatan (logistik) yang digunakan adalah sebagai berikut:

a. Kuis untuk mengetahui tingkat literasi keuangan dan kesiapan finansial peserta dalam menghadapi pensiun

b. Modul yang berisi materi diseminasi yang akan disampaikan dalam bentuk ceramah

c. Souvenir

\subsection{Pengumpulan Data dan Materi}

Data yang diperlukan untuk pelaksanaan kegiatan ini diperoleh secara langsung dari kelompok sasaran dan pengurus komunitas sasaran. Materi yang digunakan dalam diseminasi ini diperoleh dari hasil penelusuran pustaka, baik yang dikeluarkan oleh pihak pengelola dana pensiun maupun lembaga keuangan lainnya, buku, jurnal ilmiah, serta bahan pustaka lainnya.

\section{PELAKSANAAN}

\subsection{Persiapan}

Sebelum pelaksanaan diseminasi, berikut ini adalah penjelasan atas 3 tahapan persiapan yang dilakukan.

\section{a. Menghubungi Ketua Komunitas Sasaran}

Komunitas Ibu di lingkungan RT 09 RW 03 Kelurahan Dukuh Kecamatan Kramat Jati Jakarta Timur dipimpin oleh Ibu Ning Darma. Ketika kegiatan persiapan dilaksanakan, Ibu Ning sedang berada di luar kota. Atas ijin beliau, yang dihubungi melalui telepon, pelaksana menghubungi wakil ketua, yaitu Ibu Pudji untuk mendapatkan ijin. Setelah disampaikan latar belakang dan tujuan kegiatan, Ibu Puji memberikan ijin pelaksanaan kegiatan dan menetapkan jadwal kegiatan pada Minggu, 3 November 2019 pada pukul 16.00-18.00 WIB di Kediaman Ibu Sarbini, salah satu anggota komunitas.

\section{b. Menyusun Materi Diseminasi}

Materi diseminasi disusun dengan mempertimbangkan latar belakang pendidikan dan usia sasaran. Data pendidikan dan usia sasaran diperoleh dari wakil ketua komunitas. Umumnya mereka berpendidikan Sekolah Menengah Atas (SMA) dengan rentang usia 
diantara 32 tahun hingga 70 tahun. Mengingat topik kegiatan adalah perencanaan pensiun, maka fokusnya adalah pada sasaran dengan usia produktif, yaitu hingga 60 tahun. Data profil anggota komunitas tersebut menjadi pertimbangan dalam penyusunan materi agar informasi yang akan disampaikan tepat sasaran.

Materi ceramah dibuat dalam bentuk slide dan salinannya dibagikan kepada peserta. Materi tersebut meliputi definisi pensiun, kriteria pensiunan yang sejahtera, pengenalan terhadap sumber-sumber keuangan di masa pensiun, jenis-jenis lembaga pensiun, hak dan kewajiban peserta dana pensiun, dan beberapa kegiatan produktif yang disarankan dilakukan dalam masa pensiun.

Dalam rangka memancing perhatian peserta, disiapkan pula sejumlah pertanyaan terkait rencana pensiun yang sudah dipikirkan oleh para peserta dan sebuah cerita tentang seorang pensiunan yang tetap sejahtera dan bermanfaat bagi orang lain. Diharapkan pertanyaan dan cerita tersebut juga dapat meningkatkan kesadaran peserta tentang pentingnya melakukan perencanaan pensiun.

\section{c. Menyiapkan Logistik Kegiatan}

Logistik yang diperlukan adalah fotokopi materi, daftar hadir, dan souvenir. Sejumlah 30 paket logistik disiapkan untuk dibagikan kepada peserta. Souvenir yang diberikan adalah jilbab (Lampiran 1).

\subsection{Pelaksanaan Kegiatan}

Kegiatan ini diselenggarakan pada Minggu, 3 November 2019 jam 16.00-18.00 WIB bertempat di Kediaman Ibu Sarbini, yang merupakan anggota komunitas sasaran, yang beralamat di RT 09 RW 03 Kelurahan Dukuh Kecamatan Kramat Jati Jakarta Timur.

Realisasi susunan acara adalah sebagaimana terlihat pada Tabel 2. Kegiatan dihadiri oleh 18 orang dari 30 orang anggota komunitas.

Tabel 2.

Realisasi Susunan Acara

\begin{tabular}{|c|l|l|}
\hline Jam & \multicolumn{1}{|c|}{ Kegiatan } & \multicolumn{1}{c|}{ PIC } \\
\hline $16.00-16.10$ & Pembukaan & Ketua Komunitas: Ibu Ning Darma \\
\hline $16.10-16.40$ & Ceramah & Farida Komalasari \\
\hline $16.40-17.40$ & Tanya Jawab \& Diskusi & $\begin{array}{l}\text { Farida Komalasari } \\
\text { Eko Ganiarto }\end{array}$ \\
\hline $17.40-17.50$ & Penutupan & Ketua Komunitas: Ibu Ning Darma \\
\hline $17.50-18.00$ & Pembagian Souvenir & Wakil Ketua Komunitas: Ibu Puji \\
\hline
\end{tabular}




\subsection{Evaluasi Kegiatan}

\section{a. Evaluasi atas Kelompok Sasaran (Who)}

Dipilihnya Komunitas Ibu di lingkungan RT 09 RW 03 Kelurahan Dukuh Kecamatan Kramat Jati Jakarta Timur sebagai sasaran kegiatan ini adalah berawal dari keprihatinan pelaksana atas banyaknya penduduk usia lanjut di lingkungan tersebut yang kehidupannya di usia pensiun sangat terbatas, bahkan beberapa mengalami kesulitan keuangan. Disamping menjadi beban bagi dirinya sendiri, keberadaan penduduk usia lanjut tersebut juga menjadi beban generasi keduanya. Kondisi ini mengakibatkan beban generasi kedua (anak/menantu) menjadi berat, karena disamping membiayai rumah tangganya sendiri juga harus menanggung biaya orang tuanya. Oleh karena itu, untuk mengurangi permasalahan tersebut, kiranya diperlukan upaya untuk meningkatkan kesadaran masyarakat terhadap pentingnya melakukan perencanaan pensiun.

Berdasarkan uraian tersebut, maka pemilihan Komunitas lbu di lingkungan RT 09 RW 03 Kelurahan Dukuh Kecamatan Kramat Jati Jakarta Timur sebagai kelompok sasaran pada kegiatan ini adalah sangat tepat.

\section{b. Evaluasi atas Alasan Pemilihan Topik (Why)}

Topik perencanaan pensiun dipilih berdasarkan pengamatan yang telah dilakukan sebelumnya. Pengamatan yang dilakukan sebelum penetapan topik kegiatan meliputi pengamatan terhadap standar hidup penduduk usia pensiun, tingkat pendidikan anggota kelompok sasaran, dan usia anggota kelompok sasaran. Oleh karenanya topik perencanaan pensiun dinilai sangat dibutuhkan oleh kelompok sasaran. Hal ini terlihat dari tingginya antusiasme peserta dalam mengikuti kegiatan, sejak awal hingga akhir.

\section{c. Evaluasi atas Materi (What)}

Setelah dilakukan pemilihan topik, selanjutnya disusun materi sebagaimana telah diuraikan pada Bab 4.2 di atas. Materi tersebut ternyata sangat dibutuhkan dan mudah dipahami oleh para peserta. Peserta menyetujui tentang pentingnya perencanaan pensiun. Peserta menyatakan paham terhadap materi yang disampaikan dan dirasakan memberikan manfaat yang besar dalam pengelolaan keuangan rumah tangga masing-masing.

Pada saat dilaksanakan diskusi, 7 orang menyatakan sudah mulai memikirkan namun belum melakukan perencanaan pensiun. Sedangkan sisanya sama sekali belum memikirkan perencanaan pensiun. Namun ketika dikonfirmasi apakah melakukan perencanaan pensiun dan menerapkannya penting untuk hari tua mereka, semua menjawab penting. Oleh karenanya langkah berikutnya adalah memberikan pelatihan tentang teknik melakukan perencanaan pensiun, yang sifatnya sangat customize, tergantung pada usia dan kekuatan keuangan rumah tangga masing-masing. 


\section{d. Evaluasi atas Tempat Penyelenggaraan (Where)}

Salah satu rumah warga yang merupakan anggota komunitas menjadi pilihan sebagai tempat untuk mmenyelenggarana kegiatan. Acara diselenggarakan di teras depan, ruang tamu, dan ruang keluarga, sehingga peserta terbagi menjadi tiga kelompok. Akibatnya komunikasi antara pemberi materi dengan peserta terasa kurang leluasa karena terhalang tembok dan penyekat ruangan. Disarankan agar kegiatan sejenis di masa yang akan datang dapat diselenggarakan di tempat yang lebih luas sehingga peserta tidak tersekat-sekat (Lampiran 2).

\section{e. Evaluasi atas Jadwal dan Durasi Penyelenggaraan (When)}

Kegiatan ini diselenggarakan pada Minggu, 3 November 2019, dimulai dan diakhiri tepat waktu, yaitu pada jam 16.00-18.00. November merupakan waktu yang tepat karena sebagian besar peserta adalah karyawan yang biasanya akan menerima bonus pada bulan Desember. Dengan demikian mereka sudah bisa mulai memikirkan penggunaan penerimaan bonus untuk mendukung impian memasuki masa pensiun yang sejahtera.

Penyelenggaraan kegiatan pada sore hari merupakan waktu yang paling tepat karena peserta adalah para ibu rumah tangga yang memiliki banyak kegiatan dalam kaitannya sebagai ibu rumah tangga, yang dilaksanakan pada pagi hari. Sebenarnya diharapkan jumlah yang hadir adalah 30 orang, yaitu seluruh anggota komunitas. Namun kenyataannya hanya 18 orang yang hadir.

Durasi penyelenggaraan selama dua jam dirasakan sangat tepat karena cukup untuk memberikan materi dengan metode ceramah, dilanjutkan diskusi dan tanya jawab, serta permainan sederhana. Jika waktunya lebih panjang, dikuatirkan para ibu akan merasa bosan dan akan meninggalkan tempat sebelum acara berakhir.

\section{f. Evaluasi atas Metode/Cara Diseminasi yang Digunakan (How)}

Metode ceramah dan active learning yang digunakan terbukti mampu menarik perhatian peserta. Sepanjang 2 jam kegiatan terlihat bahwa seluruh peserta mengikuti kegiatan dengan seksama.

\section{PENUTUP}

Kesejahteraan ketika menjalani usia pensiun adalah keniscayaan. Banyak rumah tangga yang tidak melakukan perencanaan pensiun dengan baik. Akibatnya kesejahteraan di usia pensiun menjadi jauh dari kenyataan. Oleh karenanya kesadaran melakukan perencanaan pensiun perlu dibangun sejak dini. Jika kesadaran telah terbentuk maka 
diperlukan bimbingan dalam menyusun rencana pensiun. Hal ini perlu dilakukan mengingat secara rata-rata, tingkat literasi keuangan pengelola rumah tangga di Indonesia masih rendah.

Kegiatan ini sangat bermanfaat bagi masyarakat dalam membangun hari tua yang sejahtera. Kegiatan ini telah menyadarkan para peserta tentang pentingnya melakukan perencanaan pensiun. Oleh karenanya diperlukan kegiatan lanjutan dengan topik teknik menyusun perencanaan pensiun. Diharapkan kegiatan lanjutan dapat segera diselenggarakan sehingga tidak melunturkan kesadaran yang telah terbangun.

\section{UCAPAN TERIMA KASIH}

Kegiatan ini terselenggara karena adanya dukungan dari berbagai pihak. Oleh karena itu kami mengucapkan terima kasih kepada:

a. Rektor President University

b. Direktur Lembaga Riset dan Pengabdian Masyarakat President Univrrsity

c. Ketua Komunitas Ibu-ibu RT 09 RW 03 Kelurahan Dukuh Kecamatan Kramat Jati Jakarta Timur

serta kepada pihak-pihak lain yang tidak dapat kami sebutkan satu per satu.

\section{REFERENSI}

finansialku.com. 2018. Ibu Rumah Tangga Butuh Konsultasi Perencanaan Keuangan. Diunduh dari https://www.finansialku.com/ibu-rumah-tangga-butuh-konsultasiperencanaan-keuangan/

Guarav, M. 2018. Financial Planning. Diunduh dari https://www.google.com/search?q=distribusi+keuangan+rumah+tangga\&client=firefo $x-b$-ab\&source $=$ Inms\&tbm $=$ isch\&sa $=X \& v e d=0$ ahUKEwjWmOHgh7bAhVHXisKHQQVA70Q_AUICigB\&biw=1600\&bih=786\#imgrc $=\operatorname{td} 5 \mathrm{mzJRKuZ} \_x M$ :

https://www.google.com/search?q=asset+allocation+on+households\&client=firefox-b$\mathrm{d} \&$ source $=$ Inms\&tbm $=i s c h \& s a=X \& v e d=$ OahUKEwil7Zf0x9PhAhUBPo8KHWUMCq8Q_AUIDigB\&biw=1600\&bih=786\#imgrc= AvusrBzxAaCyBM

Komalasari, F. dan Hani, N.R.A. 2018. Behavioral Intention of Early Retirement Among Indonesian Worker. Skripsi. Cikarang: Universitas Presiden.

Komalasari, F. dan Ganiarto, E. 2018. Diseminasi Pola Pengelolaan Keuangan Rumah Tangga: Perencanaan Biaya Pendidikan. Laporan PKM. Cikarang: Universitas Presiden.

Kontan. 4 Oktober 2017. OJK: Literasi Keuangan Masyarakat Masih Rendah. Diunduh dari https://keuangan.kontan.co.id/news/ojk-literasi-keuangan-masyarakat-masih-rendah 
money.kompas.com. 6 Juni 2016. Ini 3 Strategi Cerdas untuk Mepersiapkan Dana Pensiun Sejak Dini. Diunduh dari https://money.kompas.com/read/2016/06/06/120000426/Ini.3.Strategi.Cerdas.Mempe rsiapkan.Dana.Pensiun.Sejak.Dini.

OJK. 2016a. Literasi Keuangan Indonesia Kalah dari Malaysia. Diunduh dari liputan6.com

OJK. 2016b. Siaran Pers 9 Juni 2016: Safari Ramadhan OJK Berikan Literasi Keuangan bagi Masyarakat Pesantren untuk Meningkatkan Utilisasi Tabungan "Simpel". Diunduh dari ojk.go.id.

OJK, 2017. OJK: Literasi Keuangan Masayarakat masih Rendah. Diunduh dari kontan.co.id

\section{LAMPIRAN}

Lampiran 1.

Foto Souvenir

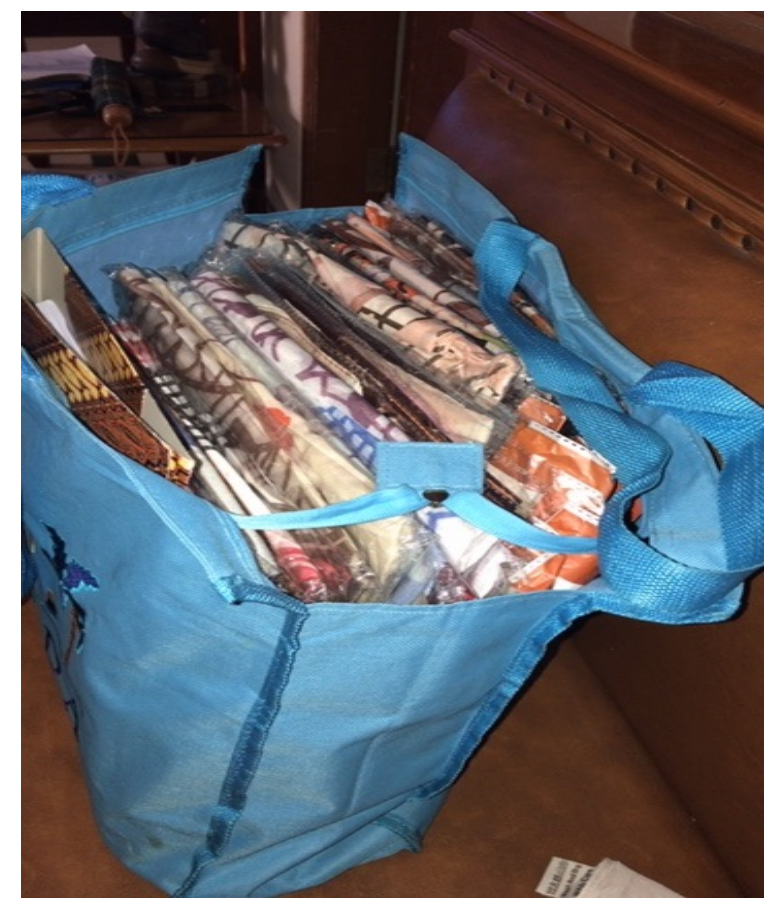


Academics in Action Journal

Volume 2, Number 2, 2020, 72-81

Lampiran 2.

Foto Kegiatan
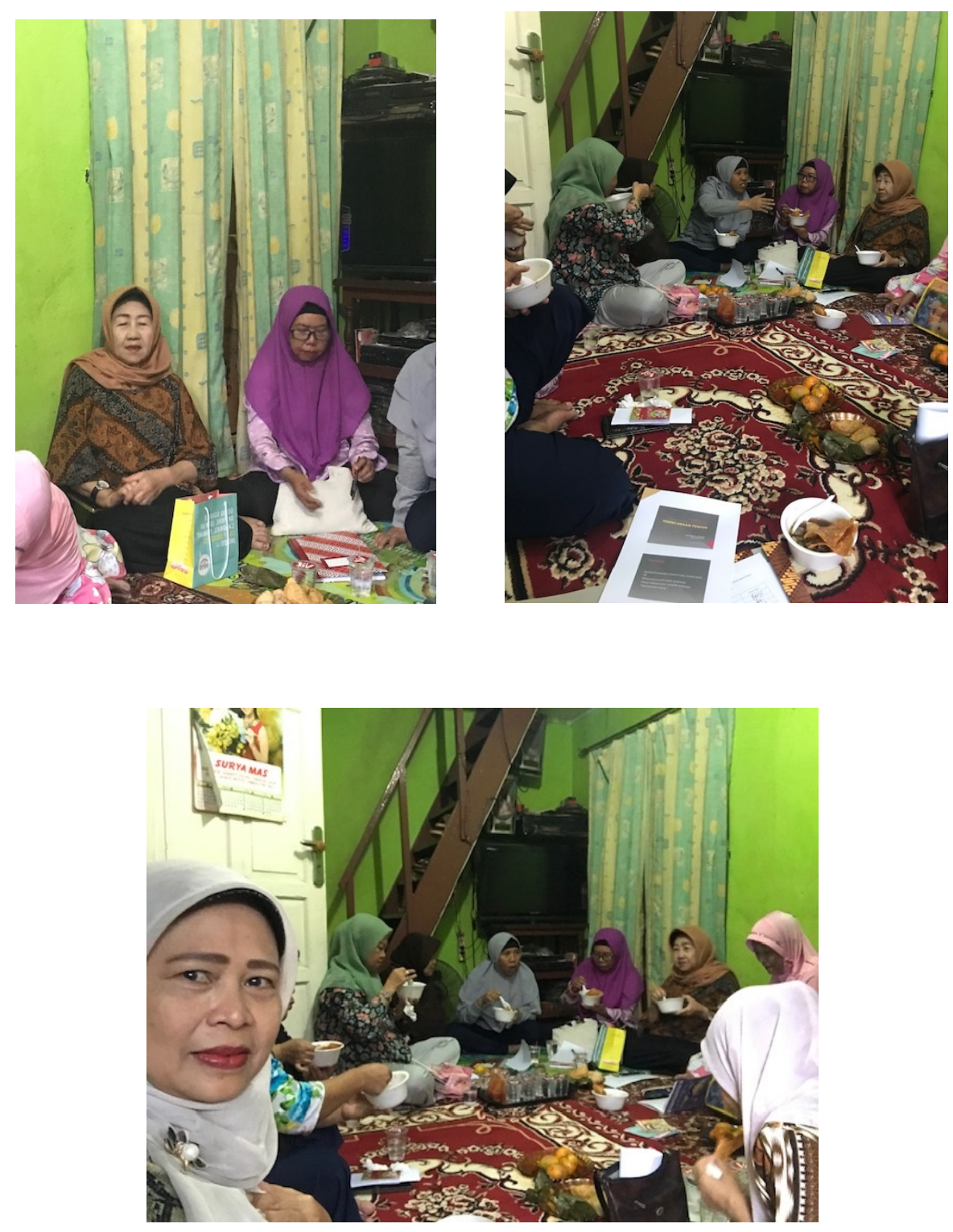